\title{
writing, with, t/error \\ And Calling on the Body of an Artist LISA MCDONALD
}

A friend told a story about souvenirs. A difficult story. Discomfiting. Raw. About ash and death and small vials of both that were sold on the streets of New York in what followed a colossal collapse, a 'catastrophe of immense proportions'. Another time, another truth, and a new philosophical turn. After the buildings and bodies fell, I wondered where all the ash went and how long it stayed wherever that was: the interstices of the city, the gutters, the streets, the drains. The pores of the skin, the lining of a breath, the air. Other spaces of molecular transformation.

With nature and biology newly recalled as sites for reviewing what constitutes the corporeal in humanities thought, it seems again permissible to inspect the interior of bodies, and to render anew the abandoned and external traces of the intracellular. This practice involves a disciplinary sway across themes of t/error and conviction, a momentary and perilous fluency between alteration and resolve.

Along similar lines, it is thought that art making engages a deliberative ethos set amid the select particularities of the stay, the logic of creative arrest: 'this' moment, 'this' view, 'this' shape, 'this' making - a halting gait as lively as that of one letter following (in front of) another. This has also been thought a 'practice of disaster', a gesture of the immediate and the arcane which is more than merely the outline of political making.

Experimentally then, this paper asks what's wrong with the occasional fix if the fixing is already 'strangely familiar'? 


\section{- ReVIVAL: OF T/ERROR}

With its signifier emptied, and the world a-shudder, it seems prosaic to begin with the questions, 'What is terror?' 'What distinguishes [terror] from fear, anxiety, and panic?' 'The philosopher Jacques Derrida once commented in this very way, but went on to say that

[s] emantic instability, irreducible trouble spots on the borders between concepts, indecision in the very concept of the border: all this must not only be analysed as a speculative disorder, a conceptual chaos or zone of passing turbulence in public or political language. We must also recognize here strategies and relations of force. ${ }^{2}$

Following this appeal, I'd like to continue with two possible directions for thinking fixity which have a bearing on how to consider the themes of 'comfort' and 'terror' proposed by the presence of artwork at the 2005 Cultural Studies of Australasia conference, Culture Fix. ${ }^{3}$

In her delivery of a recent National Press Club Address, '2005 Australian of the Year' Dr Fiona Wood spoke passionately about her science, the science of cellular regeneration, calling for a collaborative emphasis in the provision of public health care outside the usual medical sphere. Wood and her colleague Marie Stoner are responsible for developing skin tissue engineering technologies called ReCell and Cellspray, which, with recent commercialisation, have radically transformed clinical burns practices, encouraging, in Wood's terms, 'scar-less, painless healing' for burns injuries. ${ }^{4}$ Brought to public attention after the 2002 bombings in Bali, these technologies work by 'culturing a small piece of the patient's skin in enzymes, then spraying the solution onto the wound, after which the live skin cells multiply and quickly cover the damaged area'. ${ }^{5}$ The main advantage this has over existing skin culture practices is that the cultured skin is rendered useable within a much shorter time, taking only thirty minutes to mature, compared with the five days, and beyond, which would otherwise be needed. The reduction in time decreases the incidence of infection, and significantly improves the patient's chances of survival. ${ }^{6}$

I have recently reinterviewed the scientist Alexandria Richmond, who specialises in reproductive science-specifically in the area of somatic cell fertilisation, or the making of any cell in the body, potentially, into a sperm cell, with a bit of chemical help. ${ }^{7}$ Richmond conveyed that human reproduction, as we currently understand it, could be significantly revised through this process, even though the procedure was originally intended to assist men who were infertile, or had, for some unexpected reason, become so.

Somatic cell fertilisation is based on the insertion of a body cell, rather than a sperm cell, into an egg cell. Unlike a sperm cell, which carries one set of chromosomes, a body cell carries two sets, so the egg is chemically induced to shed one set of chromosomes from the 
body cell and one from itself. This leaves two sets of chromosomes out of which an embryo begins to grow in vitro. It is later implanted into a womb. ${ }^{8}$ The method has been successfully trailed in mice, so at least at the level of the rodent, the much mythologised process of embryogenesis is rendered through the inherently unsettled nature of bodies and the influence of alteration.

These two directions stress a re-emerging problematic within humanities thought brought about by the interrelationship between the volatile area of the biological sciences and cultural life- a problematic hinged on logics of disturbance, and, in Isabelle Stengers's terms, 'adventure[s] of hope', ways to explore the inherently experimental nature of science through the conceptual spaces of disorder, unrest, and anticipation. ${ }^{9}$

I began researching the cultural life of science a few years ago as part of my doctoral studies, which were then concerned with negotiations of new fertility technologies experienced by people of diverse sexual identities. I remain surprised by how compelling the various extensions of science into cultural life are, securing science as already more than itself. I now wonder about the future of cultural research in the post-genetic moment, and what form it will take. Much is yet to be thought, and written, on the 'new gene' and the 'smart cell', and still more to be actualised, whether in practice or myth.

My views are influenced by those of the digital artist Mark Amerika who has inquired into academic research practices, asking how the deliberative methods of artists could interrupt established and conventional approaches to knowledge making in the humanities. Speaking particularly on notions of 'the digital', Amerika has asked how artists might be able to "strategise a ... "digital poetics", that troubles existing methods of inquiry into what constitutes digital concepts. ${ }^{10}$ In the communications and media areas, conventional methods seem fairly comfortably settled into the now predictable tropes of cultural mediation, content analysis, and digital convergence. What could a poetics of 'parallel strategies' offer these kinds of directions? And could anything new emerge from enabling these kinds of risks?

Similarly, we can ask what could become of the often-fraught relationship between the apparently distinct areas of the 'hard sciences' and the humanities. The alliance is habitually uneasy. Loitering in the 'hard sciences' can make the humanities researcher, like the figure of the romantic fool in Barthes' A Lover's Discourse, 'stupid', 'dense', 'dim-witted', where the absence of surety secures the often wordless volatility of an outsider's fretful competence. ${ }^{11}$ We arrive at the table of 'non-knowledge' philosophically fraught, and materially insubstantial. Correspondingly, scientists often feel betrayed by those of us in the humanities who venture too far, making off with ideas we know little or nothing about, artfully revising them into anything but science. But in Brian Massumi's thoughts, these moments are also acts of 'respectful betrayal', for it is worth remembering that 'poaching a scientific concept in no way prevents it from continuing to function in its home environment'. ${ }^{12}$ His point being that 
'the humanities need the sciences ... a lot more than the sciences need the humanities'. ${ }^{13}$ Accordingly, the hesitant vocabulary an outsider develops is awkward, subsistent and on the move: a fugitive's travelogue from the interior of knowing.

This is, of course, the point. As Isabelle Stengers has proposed, it is not simply a case of examining ideas, but of considering if we can be made to sense and imagine in new ways. Alliance with the sciences certainly offers risk, but is it always so different in approach? Stengers has proposed that science leads us towards a 'passion [for] creating new possibility', and not simply towards the arrogance or sense of power which comes with discovery. ${ }^{14}$ Importantly, in science, possibility arrives by way of similitude, through a deliberative ethos based on comparison: a likeness to a certain 'truth' by means of experimentation. In this sense, scientific evidence is more 'reliable testimony' than fact, a testimony which turns on connections between faith and reciprocity. '[I]t is the faith that if they try hard enough they should be able to get reliable witnesses, to produce ... events again and again ... [which] is [also]', Stengers notes, 'the motor of experimental science. ${ }^{15}$ It is only 'when the term reliable changes to mean something which will satisfy methodological norms' that scientific possibility signals something more dangerous. ${ }^{16}$

Similar concerns have been expressed in the humanities with one writer suggesting that it is the assertion of truth which hinders the 'spirit of inquiry' so necessary for interdisciplinary exchange. While still returning us to the thorny issue of origin, and writing specifically from the field of sociology, Steven Thiele points out that a particularly moralising form of 'biophobia' segregates the interdependence of biological and social life at disciplinary and theoretical levels. ${ }^{17}$

But I am not interested in perpetuating the now predictable tensions surrounding nature-nurture debates, nor to necessarily search for similarities between them, because examples such as these support what Elizabeth Grosz has already shown, and that is that any consideration of social life in the social sciences is embedded with ontological concerns even though the 'more modest propositions of epistemology', its concern with the production and validity of knowledges, continue largely unexamined. ${ }^{18}$

Grosz has suggested that the "critique of metaphysics that revitalized the natural sciences helped generate the social sciences, and effectively transformed philosophy during the earliest years of the twentieth century'. The distance we have created between ontology and epistemology impedes 'the capacity to provide political critiques of epistemologies, for', as she states, 'we lose access to what is outside, to the outside of knowledges, to what they leave out, transform, or cannot know'. ${ }^{19}$ In this regard, and given the presence of the 'smart cell' in postmodern scientific turns, what needs to be asked of the sciences now necessarily forces the opportunity to reconsider humanities' departures from strict biological determinism, especially when we know that what is established in science is not routinely resolved there. 
One reason why somatic cell experimentation could be of interest more broadly is because of its emphasis on variability from within zones of delineation: while the notion of a cell engages a logic of margins (interior/exterior), what cloning techniques have shown is that certain cells, the egg cell in particular, can force the remodelling of other cells to become what is needed, albeit under certain conditions. ${ }^{20}$ Following Derrida's appeal, how might we imagine this twist in the reproductive tale which offers 'conceptual chaos' from within the techno/scientific sphere, as well as significant revision of material 'relations of force', in this instance, operating at the levels of sex and gender? ${ }^{21}$

In response to Fiona Wood's call, the grasp for collaborative, or truly interdisciplinary, knowledge thus involves a fixity which is buoyed by the 'fuzzy' logic of interdependence. The purpose of this sometimes exasperating meandering is to hunt down tactics which interrupt the often combative manoeuvres of exhaustive analytical methods. No conquest or epiphany is required. Instead, the pursuit of a less agonistic momentum inspires a new type of confidence, one which effects the writer Grace Paley's insistence that we 'write what [we] don't know about what [we] know'.22

\section{- Residue: a CAll}

Elaine Scarry has written that 'all art ... [is] counterfactual'. Art 'seek[s] to dislodge [the] surfaces [upon which it is] displayed'. ${ }^{23}$ In this way, art is 'transparent', not in the sense of it being clear or palpable, but in its permeability towards other densities of thought and their negotiation. But it's tempting to use art as illustrative of something other. We are bothered by its self-consciousness, by its ability to state its own rationale, offer its own commentary. It is relatively straightforward to speak 'about' art within an anxiously representative system, even though cultural studies has made us aware of the 'singularity of existence', of the limits of textuality. ${ }^{24}$ But how can one speak art itself? How can one find and articulate the immediacy of what art attempts? Of what might be brought into view, but be already beyond view? Of what can be only momentarily noticed through what Linda Walker has called an 'archaeology of surfaces', ${ }^{25}$ the unearthing of what 'is', but what is 'discernable only in and through [its] invisibility'. ${ }^{26}$ Like the flux of meaning stripped bare, this type of singularity, while apparent through experiential dimensions, is thus also a space of conceptual wreckage, '[a] kind of sense without sense. A sense that is multiple and excessive, and yet beyond its own inscribed ... destiny'. ${ }^{27}$

With what must be demolition in mind, the artist and writer Stephanie Radok offers the view that 'the basis of non-Aboriginal art [in Australia] has always been an encounter between an empirical scientific vision and a strangeness. A strangeness that has become incorporated into that vision, but which changes it irrevocably and continuously'. ${ }^{28}$ This basis is also the moment where art and disturbance collide, insisting that we attend to new ways of 
understanding empiricism as well as to its abandonment, for it is not irrelevant to speak of the discarded where collisions occur. These are instants of transformation rendered through the residue of force: moments of waste on the move. Walker continues, writing that

[a] bandonment evokes the impossible. Abandonment is, in the first instance, an 'impossible' (unbelievable) thought. And then it happens. There's no way, no pattern, or model, or template, to write 'abandonment', as there are facets, façades, fractures, fragments, filaments, filings, a thousand approaches, passages, thresholds, all without knowable or definable borders, and which are all to some extent, and at the same time, out-of-bounds. ${ }^{29}$

And so my thoughts arrive again at those which recall the 'concealment' or 'secrecy' of the city, back to the spaces of molecular transformation which screen the sediments of bodies; the interstices of the city, the gutters, the streets, the drains. ${ }^{30}$ Earlier this year I viewed an exhibition of Fiona Hall's artwork, then displayed at the Art Gallery of South Australia. It is Hall's vivid criticality with the detail of biological matter which is of interest, for these are more than merely 'counterfactual' works, but play across, alongside, within, the 'force[s] of secrecy', in Michael Taussig's terms, and work to open the 'secretly familiar', or that 'which is generally known but cannot be spoken'. ${ }^{31}$ Following Bergson, they perhaps reprise 'the most visceral registers of self', the internal spaces of intuitive knowing orchestrated by an intuition which, as Bergson proposed, 'has become disinterested, self-conscious, capable of reflecting upon its object and of enlarging it indefinitely'. ${ }^{32} \mathrm{~A}$ kind of internal spontaneity which we would otherwise say we have lost in the aspirational momentum of the everyday-sublime. ${ }^{33}$ In this instance, I borrow the term 'visceral registers' from the writings on waste by Gay Hawkins, and refer particularly to Hall's 'bio-forms', which are made from the materials of rubber, glass beads, mother of pearl, silver wire, PVC pipe, and plastic, and which are placed within purpose-built vitrines. ${ }^{34}$

Thought a 'mingling of nature and non-nature' by the artist, and exploring that which nature 'throws back to us', ${ }^{35}$ perhaps by way of protest, the installations Drift Net, Fieldwork, White History, Dead in the Water, and Cell Culture, created between 1998 and 2002, carry material relevance when moved away from their symbolic function as 'transliterated body parts and other relics of science'. ${ }^{36}$ Curator Julie Ewington has written that when displayed in the vitrines, these works 'probe the histories of anthropology, science and museums in connection with colonialism', and while ' $[\mathrm{t}$ ] he ethereal architecture of the beaded works may seem fragile and decorative ... the sentiments are critical [as] beads have been a key product in the unequal trade between colonisers and colonised' ${ }^{37}$ But I find that it is the actual 'stuff', the materials, which draw me in, for, as Ewington also states, 'the use of rubber and plastic objects from plumbing connotes the social underside of modern hygiene'. ${ }^{38}$ In using 'fragments from disparate sources, and combin[ing] these into a whole that ... express[es] 
her [particular] ... "way of seeing" [Hall] incorporate[s] both the classicising and iconoclastic elements of modernism ${ }^{39}$ which are worth revisiting at this particular tactical level.

It is the evidence for an underside in Hall's work which resonates with Hawkins' thoughts on waste, and gives onto the view that waste necessarily evokes questions of purity, of what the desire for purity can impel. Writing particularly on the sewer, and in the spirit of Foucault, Deleuze, Spinoza and others, Hawkins explores 'the role of bodily discordance and the visceral register in ethical thinking and politics'. ${ }^{40}$ Making 'sense of how waste is implicated in the contingency of the political' offers moments where, in Hawkins's terms,

a politics of disturbance unsettles ... [the naturalisations of power on] cultural boundaries

$\ldots$ and renders us more alert to their effects, to their constitutive uncertainty. Disturbances

... are a forceful indicator of the multidimensionality of 'the political'. They allude to the

floating energies and forces that escape structure, that reveal the play of different forms of power on [bodies] ... [T] hey are 'the circuits of intensity that emerge as one leaves, via a kind of methodological breakout, the domain mapped out by our signs'. ${ }^{41}$

Articulated here is the lingering Cartesian disregard for the life of matter, the densities and striations of substance, its force. ${ }^{42}$ More evidence for this disposal can be found somewhere between Darwin and Freud and the so-called 'civilising processes' of the nineteenth century. In evolutionary terms the gradual practice of 'walking upright' helped leave behind the 'gastrointestinal' self. This 'rising above', in combination with the sanitizing power of the new sewer, enabled a society in which ' $[\mathrm{t}]$ he sewers bec[a]me the new Hell, the lower gastrointestinal base for the civilization resting upon it', as William Miller has written. ${ }^{43}$ But whatever reason we choose, it seems clear that matter is more than similitude can handle, for as the surrealist artist René Magritte wrote in one of his letters to Foucault, it is '[o]nly thought [that] resembles. It resembles by being what it sees, hears, or knows; it becomes what the world offers it', ${ }^{44}$ returning us to the limits of relational equivalence which characterise the semiotic model, and which continue to inform both the 'social' and 'hard' sciences.

In this context it is worth considering that the 'mingling of nature and non-nature ${ }^{45}$ in these artworks submerges us deep inside the molecular body, into 'something kinaesthetic ... something located in the bones'. ${ }^{46}$ And thus something also incorporeal and unknown, a type of sense without sense, ${ }^{47}$ and even from within the current schema of cellular knowing. Science can tell us a lot about cells, but it still can't explain how bodily genesis occurs. Yet in the aesthetic realm we are moved towards an interior rethought as its own 'methodological breakout', ${ }^{48}$ budged away from the confines of relational thinking, and down into the gritty domain of residue and irregularity. In this sense, Hall's forms thus effect the spaces of 'nonknowledge', the 'fuzzy philosophies' of disciplinary interdependence, which seem also to magnetise an intense desire for truth brought about by their peculiar, and almost relentless 
beauty. As Elaine Scarry has proposed, such desire embraces questions of fixity at the most complex level of sense-making. Works which are as breathtakingly intricate as these, also provoke

[a] state of certainty since beauty, sooner or later, brings us into contact with our own capacity for making errors. The beautiful, almost without any effort of our own, acquaints us with the mental event of conviction, and so pleasurable a mental state is this that ever afterwards one is willing to labor, struggle, wrestle with the world to locate enduring sources of conviction-to locate what is true. ${ }^{49}$

In the concern about fixity we often ignore what can be inspired by its generative potential, not simply as a point of unfettered 'departure' or 'transgression', but through nodes of assembly which insist on the struggle towards the 'whatever' moment that notices the limits of the representational grid. ${ }^{50}$ Calling on the body of an artist thus invites a sense of conviction similar to that which Scarry describes, as something which also demonstrates a capacity to err, itself the buoyant interior of that other troublesome word, 'terror', which sets its structures and syllables afloat, like something to wish for, and then capsize. In the beautiful we find potential for assurance, but paradoxically, not for knowing what is assured. Error and conviction are thus conceptual oscillations which rally together moments of certainty-truth prevails, and offers a false transcendence back into the realm of actuality.

So by 'the body of an artist' I do not mean the artist's body located subjectively within the production of the artwork, even though this can be a useful project, but a body which is something approaching the chemistry of alteration that propels organic and inorganic matter through the messy precision of molecular explosion, also at the heart of scientific theories of transformation, and notions of the durational body. A body thought not as artefactual and culturally inscribed, but a body in motion, and thus in question, of representative knowing. ${ }^{51} \mathrm{~A}$ body ready to work this tension in precariously exacting ways, for it has also been said that

[once] art is released from its duty to reveal the truth of a unified 'I' residing beneath the veil of surface appearance, it can assume the freedom to move ... across such surfaces ... [As one example] the body/[art] interface becomes a process of materialising the erotic, rather than an inscription of desire on the body. ${ }^{52}$

Radok notes this release in Hall's art making, and importantly, of her body, writing that ' $[\mathrm{t}]$ he human body, its physicality, materiality and eroticism, is very strong in Hall's work in her exceptional and excoriating methods of constructing her art, as well as in her subject matter which is never disembodied, never abstract but always grounded in physicality. The artist's hands are ever present'. ${ }^{53}$ But where Radok offers the aside that she 'sometimes imagines 
[Hall's hands] covered in cuts from all the sharp edges of metal that she [uses]', ${ }^{54}$ I suggest that what more than merely whispers from within this parenthetical frame is the existence of a fusion akin to the moments of chemical exchange responsible for the generation of life and matter. A fusion which tests the margins and limits of fluidity, and importantly, returns us to the vivid materiality of creative force, its wild and unpredictable directions.

These works do not merely borrow from scientific turns, nor necessarily demand their critique, even though they deploy much in that regard. What is offered is a form of singularity that is a struggle to articulate, a singularity which the apparent 'split' between the sciences and the humanities conceals. With these works, Hall invites us to strive towards literacies for the uncanny. Literacies which are perhaps more tidal than fluid. Sandcastle literacies, which, as Elizabeth Grosz has urged, might follow the rules 'of development, [yet are] processes that induce change, that involve innovation, emergence, and the creation of the new and the unforeseen'. ${ }^{5}$

LISA MCDONALD has lectured in communications, media, and cultural studies at the Universities of South Australia and Adelaide. She has an interest in potential relations between humanities and biological sciences philosophies which follows her doctoral research into fertility technologies and diverse sexual identities. Her art practice is situated within photo arts and digital media areas. $<$ mc_d@bigpond.com>

1. Jacques Derrida, 'Autoimmunity: Real and Symbolic Suicides: A Dialogue with Jacques Derrida', in Giovanna Borradori, Philosophy in a Time of Terror: Dialogues with Jürgen Habermas and Jacques Derrida, University of Chicago Press, Chicago and London, 2003, pp. 102-3.

2. Derrida, p. 105.

3. The exhibition Strangely Familiar was displayed at the UTS Gallery, Ultimo, Sydney, 1 November2 December 2005, and featured the work of artists Fiona Hall and Fiona MacDonald. Information about the exhibition themes can be found on the gallery website, $<$ http:www.utsgallery.uts.edu.au>.

4. Fiona Wood, National Press Club Address, Australian Broadcasting Corporation, 28 September 2005.

5. ATSE Clunies Ross Award, 'Medical science (skin tissue engineering)', October 2005 , $<$ http://www.cluniesross.org.au/cr2005/ woodstoner.htm>.
6. Kathryn Shine, 'Striving to Heal the Scars', Weekend Australian, 19-20 October 2002, p. 22. See also Biomedoz, Organisation Profile: Clinical Cell Cultures Pty Ltd (C3), <http://www.biomedoz. com.au/Organisation/profile.asp?CompanyID= 1247>; Victoria Laurie, 'Skin Deep, Mountain High', Weekend Australian Magazine, 21-22 June 2003, pp. 18-21.

7. The interview material is part of a broader project so a pseudonym has been used in the interests of subject confidentiality.

8. Penny Fannin, 'A Noble Idea Gives Birth to a Maelstrom', Age, 14 July 2001, p. 14.

9. Mary Zournazi, 'A "Cosmo-Politics"-Risk, Hope, Change: A Conversation with Isabelle Stengers', in Hope: New Philosophies for Change, Pluto Press Australia, Annandale, 2002, p. 245.

10. Mark Amerika, 'Making Space for the Artist', Rhizome.org, October 2005, <http://rhizome.org/ thread. rhiz? thread $=18799 \&$ pages $=1>$. 
11. Roland Barthes, A Lover's Discourse: Fragments, trans. Richard Howard, Penguin, Harmondsworth, 1990.

12. For a seriously playful meditation on this uneasy relationship, see Brian Massumi, 'Introduction: Concrete is as Concrete Doesn't', in Parables for the Virtual: Movement, Affect, Sensation, Duke University Press, Durham and London, 2002, pp. 1-21.

13. Massumi, p. 21.

14. Stengers in Zournazi, p. 248.

15. Stengers in Zournazi, p. 249.

16. Stengers in Zournazi, p. 249, original emphasis.

17. Steven Thiele, 'Biophobia Blocks Spirit of Inquiry', Australian, 26 October 2005 , p. 33.

18. Elizabeth Grosz, The Nick of Time: Politics, Evolution and the Untimely, Allen and Unwin, Crows Nest, 2004, pp. 17-18.

19. Grosz, p. 18.

20. See for example Lisa McDonald, 'The Spell of the Cell: Molecular Reproduction and "the genetic imaginary"', in Edyta Lorek-Jezinska and Katarzyna Wieckowska (eds), Corporeal Inscriptions: Representations of the Body in Cultural and Literary Texts and Practices, Nicolaus Copernicus University Press, Torun, 2005, pp. 238-49.

21. See again Derrida in Borradori, p. 102.

22. Grace Paley cited in Thomas Shapcott, 'The Writer's Investment in Language', in TEXT, vol. 1, no. 2, October 1997, <http://www.gu. edu.au/school/art/text/s.

I acknowledge the use of Barthes' notion of 'stupidity' and the idea of a necessarily 'fuzzy logic' in the paper Pricklings: Appearance written by Teri Hoskin and presented at the 2003 Digital Arts and Culture conference, $<$ http://hypertext.rmit.edu.au/ dac/papers/Hoskin.pdfs.

23. Elaine Scarry, 'Art on the Berlin Wall', $<$ http://www.galerie-noir.de/ ArchivesEnglish/ScarryEN.htm>.

24. See for example Lawrence Grossberg, We Gotta Get Out of This Place: Popular Conservatism and Postmodern Culture, Routledge, New York and London, 1992.

25. Linda Marie Walker, 'Approaching: The Archaeology Of Surfaces, or What Is Left Moment To Moment, or I Can't Get Over It', 2002, <http://www.unisanet.unisa.edu.au/learn/ archdesign/?PATH=/Resources/archdesign/ VADRG+Lunchtime+Seminars/\&default= Welcome.htm>.
26. See also Nikki Sullivan, 'Being, Thinking, Writing "With", in Cultural Studies Review, vol. 9, no. 1, 2003, p. 58.

27. Walker, 'Approaching',

28. Stephanie Radok, 'Trade', in Artlink, vol. 21, no. 4, 2001, pp. 52-3.

29. Walker, 'Approaching'.

30. See Gay Hawkins, 'Down the Drain: Shit and the Politics of Disturbance', in The UTS Review, vol. 7, no. 2, November 2001, p. 34, and here, referring particularly to Michael Taussig's notion of public secrecy explored in the text by the same writer, and titled Defacement, Stanford University Press, Stanford, 1999.

31. Hawkins, pp. 34-5.

32. Henri Bergson, Creative Evolution, Dover Publications, New York, 1998, p. 176.

33. Henri Bergson, Matter and Memory, Zone Books, New York, 1991.

34. For a comprehensive account of the work I draw from, refer to the exhibition catalogue produced by Julie Ewington, Fiona Hall, Piper Press, Annandale, 2005. I am especially grateful to Georgina Downey from the Graduate Studies in Art History program at Adelaide University, and to Jin Whittington at the Art Gallery of South Australia's research library for providing support and assistance with this paper.

35. Fiona Hall cited in Ewington, p. 148. Original citation in Deborah Hart, 'Fertile Interactions', Art and Australia, vol. 36, no. 2, 1998, p. 204.

36. Ewington, p. 147.

37. Ewington, p. 147.

38. Ewington, p. 147.

39. Georgina Downey, 'Stella Bowen's Anxious Interiors', ACH: The Journal of the History of Culture in Australia, vol. 24, pp. 99-113.

40. Hawkins, p. 40.

41. Hawkins, p. 33. Hawkins cites José Gil, Metamorphoses of the Body, trans. Stephen Muecke, University of Minnesota Press, Minneapolis, 1998, p. 1.

42. See for example, Peter Stallybrass, 'Worn Worlds: Clothes and Mourning', in Dan Ben-Amos and Liliane Weissberg (eds), Cultural Memory and the Construction of Identity, Wayne State University Press, Detroit, 1999, pp. 27-43.

43. William Ian Miller, 'Darwin's Disgust', in David Howes (ed), Empire of the Senses: The Sensual Culture Reader, Berg, Oxford, 2005, p. 351.

44. René Magritte, 'Two Letters by René Magritte', in Michel Foucault, This is Not a Pipe, trans. James Harkness (ed), University of California Press, Berkley and Los Angeles, 1983, p. 57.

45. Hall in Ewington, p. 148. 
46. Radok, p. 50

47. See for instance Brian Massumi, Parables for the Virtual: Movement, Affect, Sensation, Duke University Press, Durham and London, 2002, p. 5 .

48. See again Gil cited in Hawkins, p. 33.

49. Elaine Scarry, On Beauty and Being Just, Princeton University Press, New Jersey, 1999, p. 8.

50. See for instance Luce Giard (ed), 'Gesture Sequences', in Michel de Certeau, Luce Giard, and Pierre Mayol, The Practice of Everyday Life Volume 2: Living and Cooking, trans. Timothy J. Tomasik, University of Minnesota Press, Minneapolis, Minnesota, 1998.
51. See again Bergson, Creative Evolution. See also Ann Game, 'Places in Time', in Undoing the Social: Towards a Deconstructive Sociology, Open University Press, Milton Keynes, 1990, pp. 148-85. A useful discussion about reviewing the body as 'culturally inscribed' can also be found in Elizabeth Grosz, The Nick of Time, $1-14$

52. Marsha Meskimmon, Women Making Art: History, Subjectivity, Aesthetics, Routledge, London and New York, 2003, p. 106.

53. Radok, p. 51.

54. Radok, p. 51

55. See again Grosz, pp. 157-8. 